D.G. Koliushko, S.S. Rudenko

\title{
ANALYSIS OF METHODS FOR MONITORING OF EXISTING ENERGY OBJECTS GROUNDING DEVICES STATE AT THE PRESENT STAGE
}

\begin{abstract}
Purpose. The purpose of the work is to analyze the modern methods of control and determine the most effective ones for monitoring the state of grounding of existing energy objects in operation. Methodology. The analysis of the methods was carried on the basis of comparison the experimental and calculation methods for determining the rated parameters of the grounding of existing energy objects. Results. Significant imperfections of measurements of the rated parameters of the grounding with different methods and devices was established. It has been shown that the electromagnetic diagnostics is the most complete, which allows to comprehensively assess the current state of the grounding and establish the resistance of the grounding, the voltage on it, the touch voltage and the resistance of the contact joints. The deficiencies of electromagnetic diagnostics are established at the present stage and further directions of its perfection are determined. Originality. For the first time the comparative analysis of existing methods for monitoring the state of the grounding and directions for improving electromagnetic diagnostics was made. Practical value. The obtained results allow to choose the optimum method for monitoring the state of the grounding. Elimination of the revealed drawbacks of the method of electromagnetic diagnostics will improve the accuracy of the determination of rated parameters. References 17, tables 1, figures 4.

Key words: grounding device, resistance of the grounding device, grounding device voltage, touch voltage, resistance of contact joints, electromagnetic diagnostics.
\end{abstract}

Проведено аналіз і встановлено суттєві недоліки вимірювань нормованих параметрів заземлювальних пристроїв діючих енергооб'єктів при використанні різних методик та приладів. Показано, ццо електромагнітна діагностика стану заземлювального пристрою на теперішній час є найбільш повною, яка дозволяє комплексно оцінити поточний стан заземлювального пристрою та встановити значення опору заземлювального пристрою, напруги на ньому, напруги дотику та опору контактних з'єднань. Встановлені недоліки електромагнітної діагностики на сучасному етапі та визначені подальші напрямки їі вдосконалення. Бібл. 17, табл. 1, рис. 4.

Ключові слова: заземлювальний пристрій, опір заземлювального пристрою,напруга на заземлювальному пристрої, напруга дотику, опір контактних з'сднань, електромагнітна діагностика.

Проведен анализ и установлены существенные недостатки измерения нормируемых параметров заземляющих устройств действующих энергообъектов при использовании различных методик и приборов. Показано, что электромагнитная диагностика состояния заземляющего устройства в настоящее время является наиболее полной и позволяет комплексно оценить текущее состояние заземляющего устройства и определить значение сопротивления заземляющего устройства, напряжения на нем, напряэение прикосновения и сопротивления контактных соединений. Установлены недостатки электромагнитной диагностики на современном этапе и определены дальнейшие направления ее совершенствования. Библ. 17, табл. 1, рис. 4.

Ключевые слова: заземляющее устройство, сопротивление заземляющего устройства, напряжение на заземляющем устройстве, напряжение прикосновения, сопротивление контактных соединений, электромагнитная диагностика.

Problem definition. The lifetime of most of the existing power facilities in Ukraine is over 30 years. During this period both the electrical installation itself and the grounding device (GD) undergo significant changes, as a result of which its electrical normalized parameters (NPs) may exceed the permissible values, and the constructive execution does not meet the requirements of the design and normative documentation. There are a number of factors that significantly affect the state of the GD and its parameters:

- effect of corrosion on the elements of the GD (violation of the integrity of the grid and damage of grounding conductors on the boundary of the earth-air);

- incorrect restoration of the grounding of old and connection of new units of equipment to the existing GDs (serial connection of equipment, connection to metal parts that are not connected with GD);

- damage of the GD during excavation as a result of replacement or repair of equipment;

- increase of electrical power of installation with increasing values of short-circuit (SC) currents (exceeding the permissible values of the NP of the GD).

For the estimation of GD operational capacity, NPs
[1] are used, which are periodically monitored throughout the lifetime [2]. These include: resistance of the GD, the voltage on the GD, the touch voltage and the resistance of the contact joints. These values depend on the following factors: the structural performance of the GD, the electrophysical characteristics of the soil (resistivity and thickness of the layers) and the characteristics of the object (the value of SC current, time of protection, voltage class, etc.).

The goal of the work is analysis of existing methods of monitoring and determination of the most effective ones for assessing the state of the GD of existing power facilities during operation.

Let us consider the most common methods of determining the NP of the GD.

1. Resistance of the grounding device and voltage on it. At present, the value of the resistance of the GD is determined by a number of methods:

1) the introduction of high current (50-100 A). The specified method is divided into several types:

- synchronous [3], which uses the voltage source of the industrial frequency. The current and voltage in the 
circuit are measured before and after the voltage source is switched on. Then the corresponding expressions determine the resistance of the GD;

- hit frequency [3], which uses an $\mathrm{AC}$ generator with frequency different from the industrial by $0.1-0.5 \mathrm{~Hz}$. As a result of the phase shift between the input current and the current flowing through the GD during normal operation, there are maxima and minima of the measured current and voltage. Voltage and current are also measured before and after switching on the generator, and the resistance value is determined by the corresponding expressions;

- input of current whose frequency is different from the industrial frequency and its harmonics by several $\mathrm{Hz}$;

2) input of low current (up to 3 A) [4]. In this case, generators with different from the industrial frequency are used;

3) calculation method [5-9].

Measurement according to the given methods is carried out by the method of an ammeter-voltmeter, while two circuits of arrangement of electrodes [2] are used -one and two-beam (see Fig. 1). A two-beam circuit may be appropriate for measuring in conditions where the area in the location of the power unit is limited. For both circuits, one and the same measurement procedure is used:

1) generator $\mathrm{I}$ is connected to the GD $\mathrm{E}$ and the current electrode $\mathrm{C}$, which is set at a distance of $3 D$ for the one-beam and (1.5-2) $D$ for the two-beam circuit, where $D$ is the largest diagonal of the GD;

2) current value is determined by means of generator I and ammeter PA;

3) potential electrode $P$ is clogged at a certain distance $X$, for example, $50 \%$ of the distance to the current electrode (for a one-beam circuit on one straight line with a current electrode, for a two-beam one at an angle of $40-45^{\circ}$ ), and the potential is measured;

4) further, moving the potential electrode away from the GD, the potential is measured through the selected distance (for example, after $5 \mathrm{~m}, 10 \mathrm{~m}, 15 \mathrm{~m}$, etc.);

5 ) it is necessary to move the electrode $P$ to such a distance $X$ so that the value between the two adjacent dimensions does not differ by more than $10 \%$. This will mean that the point $R_{2}$ of the curve [10] is found.
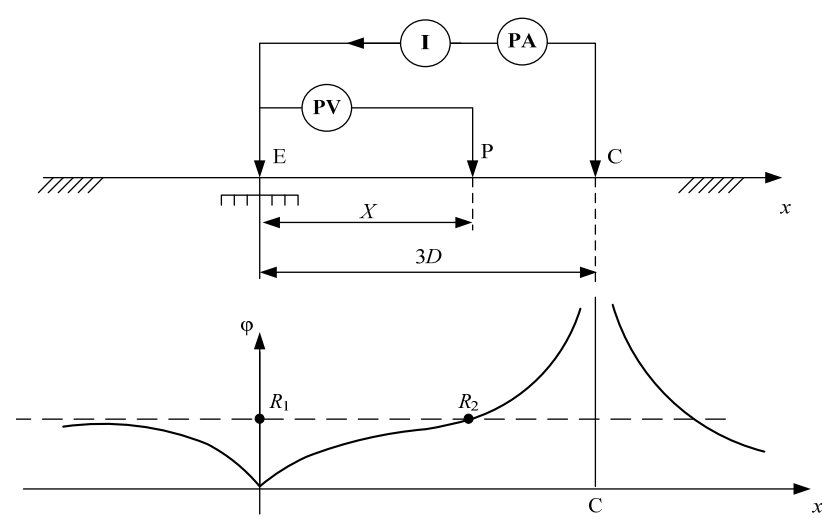

Fig. 1. Distribution of potential along the soil surface at carrying out measurements according to the one-beam circuit

The resistance of the GD in this case will be equal to the ratio of the potential at the point $R_{2}$ to the generator current. However, in practice, the most widespread, due to its simplicity, is the one-beam circuit by the $« 62 \%$ method», when the potential electrode $\mathrm{P}$ is immediately set at a distance from the GD, which is $62 \%$ of the removal of the current electrode $\mathrm{C}$. This method ensures the greatest accuracy at the condition of homogeneity of the soil, but in other cases it is necessary to use the dependence of the length of the removal of the potential electrode on the length of the removal of the current one for the two-layer soil, which is given in [10].

The horizontal part on the dependence curve of the potential on the distance to the potential electrode appears at a sufficiently large increase in the distance to the current electrode. Depending on the structure of the soil, this condition is performed at a distance to the current electrode in (3-40) diagonals of the GD. It is clear that such a diversity of measuring circuits in many cases will be impossible.

In [11], the circuit of measuring the resistance of the GD with a three-electrode installation is considered. Here, despite the assertion about the possibility of measurements for any soil structure, only a homogeneous structure was considered during physical modelling, and measurements on active power facilities were not carried out. In [12], it has been shown that in soils with horizontal and vertical inhomogeneities there is the only possible option for the arrangement of an auxiliary potential electrode in a one-beam measuring circuit, at which the exact determination of the resistance of the GD is possible. The given algorithm for the experimental search of this variant for a soil with an unknown geoelectric structure is complicated in terms of practical implementation.

The voltage on the GD is the voltage that occurs when the current flows from grounding to the earth between the point of current input to the grounding and the zone of the zero potential [1]. The direction of the voltage on the GD influences the state of the cable production of the power unit, the microprocessor measuring equipment and control equipment, the relay protection panels, and also indirectly on the electrical safety (the value of the voltage on the GD together with the electrophysical characteristics of the soil are decisive for the value of the touch voltage). According to [1], for power objects operating in a network with grounded neutral, the voltage on the GD is regulated as follows: the excess of the value of $10 \mathrm{kV}$ is allowed only on the GD, executed according to the touch voltage, and is not allowed on the GD executed according to requirements to resistance of the GD. In the case of a high potential beyond the boundary of the electrical installation and exceeding the value of $5 \mathrm{kV}$, it is necessary to apply means of insulation protection of communication and telemechanics cables that deviate from the electrical installation.

The easiest, but also the least accurate way to find the voltage on the GD is a direct recalculation, when measured according to the circuit in Fig. 1 the value of the resistance of the GD is multiplied by the real value of the $\mathrm{SC}$ current. The error in determining the voltage on the GD is due to inaccuracy in the measurement of the resistance of the GD and ignoring the nonlinear 
dependence of the magnetic permeability of the grounding conductors on the value of the SC current. Due to the impossibility of carrying out measurements of the resistance of the GD and the voltage on the GD on a number of objects (industrial enterprises, in the conditions of urban development, etc.), the most universal and precise method of determination becomes calculations using special software complexes. A series of papers [5-9] is devoted to the simulation of electromagnetic processes that occur in the GD during the occurrence of emergency currents. In most cases, the mathematical model of the GD located in a two-layer soil is used, in particular, using the analogous model [8] the authors have calculated more than 1000 energy facilities of Ukraine of the voltage classes $35-750 \mathrm{kV}$, and the software complex used in [5] is one from the world's most popular commercial versions. Input parameters for it are the constructive execution of the GD (its circuit, the section of grounding conductors, the depth of location), the electrophysical characteristics of the soil, the neutral mode and the value of the SC current of the investigated object.

2. Touch voltage. The touch voltage is a parameter that characterizes the electrical safety of the service personnel of the power unit. It depends on the current flowing from the GD into the ground, the resistance of the GD, the design of the GD and the electrophysical characteristics of the soil. In contrast to the measurement of the resistance of the GD, in which the amplitude of the measuring current does not play a large role (it is given depending on the method used), the touch voltage is proportional to it, although this dependence is nonlinear.

There are two ways of experimentally measuring the touch voltage. The first one is directly under the SC current, that is, in real conditions. It is dangerous and can be justified only in rare cases in exceptional situations (when carrying out tests of the most responsible GDs), therefore, it is practically not used. The second one is at measuring current, which is many times smaller than the actual SC current, with subsequent reduction of the measured touch voltage proportionally to the real SC current [2].

The measuring circuit is practically the same as for measuring the resistance of the GD, but with the special performance of a potential electrode and bypassing the voltmeter with a resistor. Fig. 2 shows the circuit of measuring the touch voltage with the help of the complex «КД3-1У» [2].

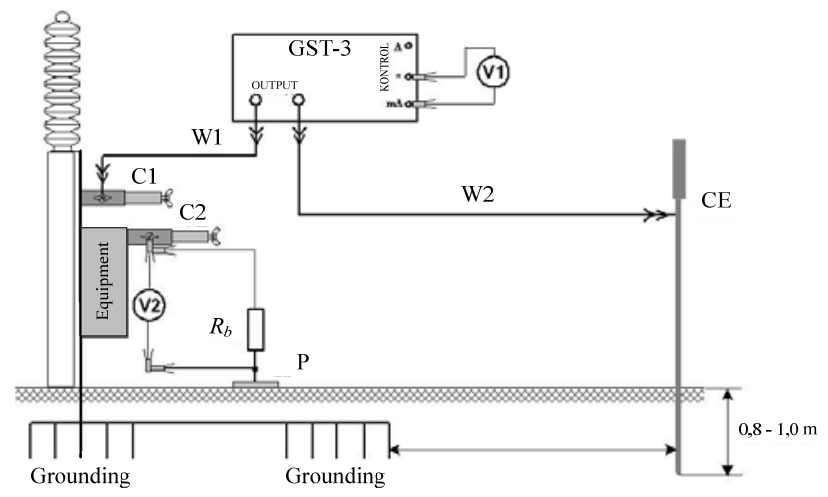

Fig. 2. Circuit for measuring the touch voltage
Potential electrode $\mathrm{P}$ must simulate two feet of a person. To do this, they use a special electrode-plate with a contact surface of $25 \times 25 \mathrm{~cm}^{2}$. To create sufficient pressure on the ground, a load of at least $25 \mathrm{~kg}$ is installed on the plate. Voltmeter is shunted by a resistor with resistance $R_{b}$. The equivalent resistance of the parallel connected resistors must be equal to the resistance of the human body (as a rule, it is assumed to be $1000 \Omega$ ). The horizontal distance from the contact point to the plate is assumed to be $0.8 \mathrm{~m}[1,2]$ or $1 \mathrm{~m} \mathrm{[7].}$

The voltmeter, in parallel with the resistor with the clamp C2, is connected between the grounded equipment (in Fig. 2, this is a control box), on which the measurement is performed, and the potential electrode. The current electrode CE is located at the same distance, as in measuring the resistance of the GD. The GTS-3 generator from the «КДЗ-1У» (or equivalent) is connected to the equipment and the CE with the help of the clamp $\mathrm{C} 1$ and wires $\mathrm{W} 1$ and $\mathrm{W} 2$, respectively. To simulate the most unfavorable seasonal conditions, the location of the potential electrode is moisturized. After that, the voltage is applied to the circuit and the voltage and current measurements are performed. The measured values of the touch voltage are reduced to the real SC current and the obtained result is compared with the acceptable normalized value. The disadvantages of this method are the impossibility of carrying out measurements under conditions of dense building and the methodological error of the method, which is connected with the ignoring of the dependence of the magnetic permeability of the grounding material on the current flowing through the elements of the GD, as well as the outflow of parts of the SC current in the grounded neutrals of transformers.

Thus, unlike the resistance of the GD, which can be determined both experimentally and by calculation, the voltage on the GD and the touch voltage at the real SC current can be found only by performing appropriate calculations using special computer programs.

3. Resistance of contact joints. One of the electrical NP of the GD is the resistance of the contact joint of the equipment with GD. In recent works, its significant influence on the voltage of the touch voltage was noted repeatedly [13-15]. The resistance of the contact joints is determined by the method of an ammeter-voltmeter at direct or alternating current using a micro-ohmmeter or double bridge [2]. The permissible value of the resistance of the contact joint is $0.05 \Omega$ at commissioning and no more than $0.1 \Omega$ during operation. The generally accepted measurement circuit for this NP, both in Ukraine [2] and abroad [7], is shown in Fig. 3.

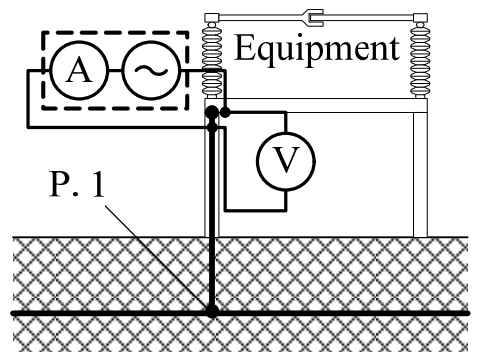

Fig. 3. Circuit for measuring the resistance of the contact joints 
Thus, according to the measurement circuit, the resistance of the contact joint implies the transient resistance between the equipment and the grounding conductor. However, as the operation of the GD and the measurements of the NP of the GD show, the excess of the touch voltage can occur as a result of violation of the integrity of the grounding conductor at the boundary of the «ground-air», as well as in connection with the increase in the resistance of the contact joint at the point of welding the grounding conductor with the GD itself (see P. 1 in Fig. 3). Therefore, the consideration of the state of the grounding conductor and the quality of its connection, and, accordingly, of the equipment itself to the GD, is an important task. To control it, we can use the resistance of the connection, which is determined relative to other grounded equipment. However, this methodology does not exist at present in order to minimize the number of required measurements.

Summing up, we can state that the above methods have the following disadvantages:

- impossibility of measuring the touch voltage, the resistance of the GD and the voltage on the GD on a number of objects due to the lack of free from communications or facilities area for the placement of auxiliary current and potential electrodes;

- incorrect measurement of the NP of the GD due to the ignoring of the length of the removal of the current electrode for two-layer soil and the absence of such dependence for three- or more layer soils;

- incorrect measurement of the touch voltage and the voltage on the GD due to the ignoring of the dependence of the magnetic permeability of the grounding conductors on the current flowing through them, and the current outflow in the grounded neutrals;

- incomplete information about the grounding quality of the equipment based on measures the resistance of the contact joints;

- technical complexity and significant labor costs when measuring the touch voltage on each unit of the equipment of the power unit (the number of such units at the $330 \mathrm{kV}$ substation can reach several hundreds, and the labor costs for measuring one point according to building codes [16] are 15 people·year).

In addition, for objects that have been in service for a long time, carrying out only measurements of the listed NPs does not allow to unambiguously assess the state of the GD: the design remains unidentified and the condition of underground grounding conductors is still unknown. Therefore, at the present stage, electromagnetic diagnostics (EMD) of the state of the GD is used for monitoring [2], which includes a complex experimental and calculation (on the basis of the real state of the GD and the results of additional experiments) determination of all NPs of the GD. The indicated method combines a number of methods: vertical electrical sounding of soil, induction method for determining the presence of grounding conductors, low current method, calculation method, etc.

4. Method of electromagnetic diagnostics of the state of the grounding device. The method of EMD of the GD [2] of active energy facilities as a whole is in line with international Standards [7, 10] and involves three stages: the experimental, calculation and the stage of issuance of recommendations.

At the first stage, the following is performed:

- determination of the constructive implementation of the GD with the help of an induction method (location and depth of groundings), which is also needed for the construction of its mathematical model;

- measurement of the imaginary specific resistance to determine the electrophysical characteristics of the soil (specific resistance, thickness of the layers and their amounts) by the method of vertical electrical sounding;

- measurement of electrical parameters (base resistance, resistance of the GD, touch voltage, and voltage on the GD with respect to another grounded point) based on the ammeter-voltmeter method and known circuits, which are necessary to assess the adequacy of the mathematical model to the real GD.

The results of experimental studies, together with the characteristics of the energy object (voltage class, neutral mode of transformers, and the values of SC currents and protection time) are the input data for the second (calculation) EMD stage.

In carrying out calculations in the second stage, the mathematical model of non-equipotential GD, located in a three-layered conducting soil with plane-parallel separation boundaries developed by the authors [9] is used. In order to determine the input soil parameters, the means of interpretation of the vertical electrical sounding and ground equivalence curves are used. The simulation of processes in the GD is performed at real SC current, taking into account the nonlinear dependence of the magnetic permeability on its value, the skin effect and the real spread of emergency currents (including outflows in a grounded neutral), which allows determining the values of the NPs even for those objects that located in a concise building or on the territory of industrial enterprises. Existing software and mathematical models allow to take into account the two- and three-layer geoelectric structure of the soil and to cover more than $80 \%$ of the energy objects of Ukraine.

In the third stage, the development of recommendations made by the requirements of normative documents for the constructive implementation of grounding conductors is carried out, as well as on the basis of comparison of the values of calculated and acceptable parameters the feasibility of introducing additional recommendations for the reconstruction of the grounding device is evaluated. After this, a recalculation is made taking into account the recommended additional groundings. Synthesis of these recommendations is a complicated technical task, since when it is solved, it is necessary to determine the optimal places for laying grounding conductors for saving labor and material costs, and at the same time, the most complete use of existing GD.

Thus, the EMD method for the state of the GD allows to carry out the most objective assessment of the current state of the GD and to develop ways to bring it in line with regulatory documents. 
To defects of the EMD of state of the GD we should include errors in determining the constructive implementation of the GD and the influence of assumptions adopted in the construction of the mathematical model:

- error of determining the depth of the GD;

- variable section of groundings on different parts of the GD, which is difficult to consider;

- errors in the identification of horizontal groundings (acceptance of cables and underground communications as an artificial grounding);

- problems with finding the location of the installation of the vertical grounding and the lack of a method for determining its length;

- assumption of a flat-parallel multilayer soil structure, which in fact has slopes and local inclusions;

- insufficient depth of sounding of multilayer soils and lack of interpretive means.

5. Devices for monitoring the state of the grounding device. In Ukraine, the domestic complex for the diagnosis of the state of the GD «КД3-1У» [2] (see Fig. 4,a), the French devices C.A 6460 and C.A $6470 \mathrm{~N}$ (see Fig. 4,b) are used, as well as domestic standard devices of the Soviet design: M-416 or $\Phi$ 4103-M1, which for the present time are used by insulation services and high-voltage laboratories at different power units.

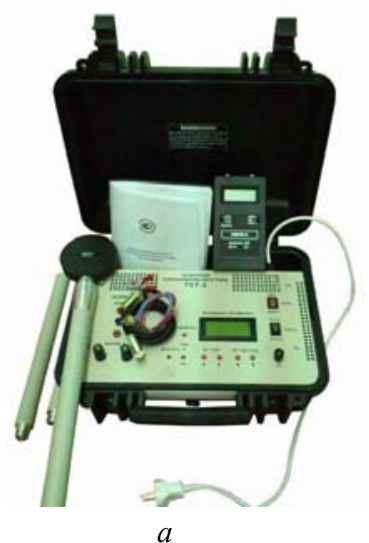

Fig. 4. Devices for monitoring the state of the GD: $a-\ll$ КД3-1У»; $b-$ C.A $6470 \mathrm{~N}$

Table 1 presents a comparison of the functions of the most common devices for monitoring the state of the GDs of operating power facilities of Ukraine.

Table 1

\begin{tabular}{|l|c|c|c|c|c|}
\hline $\begin{array}{c}\text { Device } \\
\text { name }\end{array}$ & $\begin{array}{c}\text { GD } \\
\text { state }\end{array}$ & $\begin{array}{c}\text { Resistivity } \\
\text { of the soil }\end{array}$ & $\begin{array}{c}\text { GD } \\
\text { resistance }\end{array}$ & $\begin{array}{c}\text { Touch } \\
\text { voltage }\end{array}$ & $\begin{array}{c}\text { Contact } \\
\text { joints } \\
\text { resistance }\end{array}$ \\
\hline $\begin{array}{l}\text { «ДЗ- } \\
\text { 1У» }\end{array}$ & + & + & + & + & + \\
\hline $\begin{array}{l}\text { С.А } \\
\text { 6470N }\end{array}$ & - & + & + & + & + \\
\hline С.А 6460 & - & + & + & + & + \\
\hline $\begin{array}{l}\text { Абрис- } \\
\text { 12/8 }\end{array}$ & + & - & - & - & - \\
\hline $\begin{array}{l}\text { Ф 4103- } \\
\text { М1 }\end{array}$ & - & + & + & - & - \\
\hline М-416 & - & + & + & - & - \\
\hline ЕР-331 & - & - & - & - & + \\
\hline
\end{tabular}

The analysis of devices shows that only «КД3-1У» allows to carry out a full range of works for the EMD of the GD state. However, the disadvantage of the device is the lack of autonomous power and the small size of the permissible resistance of the measuring electrodes (which practically makes it impossible to conduct soil sounding with specific resistance of more than 350 $\Omega \cdot \mathrm{m})$. The devices EP-331 and Арбис-12/8 are narrowcut and allow only measuring the resistance of the contact joints and finding the trajectory of the grounding lines, respectively. $\Phi$ 4103-M1 and M-416 are technically outdated and also have a narrow spectrum of application. C.A 6460 in comparison with C.A $6470 \mathrm{~N}$ has only one frequency of measurement and does not allow conducting sounding of soil for power units in the class of voltage $220 \mathrm{kV}$ and above. In general, a detailed analysis of the characteristics and capabilities of instruments for soil sounding is made in [17].

Thus, the most wide-ranging possibilities for determining the NPs of the GDs have «КД3-1У» and C.A $6470 \mathrm{~N}$. Looking forward to improving the «КД3-1У» or developing a similar device without indicated shortcomings.

\section{Conclusions.}

1. An analysis of modern methods of monitoring the state of the GDs has been carried out and it has been established that, unlike the determination of the resistance of the GD, which can be done both experimentally and using calculations, the voltage on the GD and the touch voltage at the real current of ground fault should be found only by calculation using special computer codes.

2. It has been shown that the method of the EMD of the GD allows to carry out the most objective assessment of the current state of the GD and to develop recommendations for bringing it in line with the normative documents.

3. The disadvantages of the EMD of the GD that are associated with errors in determining its constructive execution and the influence of assumptions made when constructing a mathematical model are established.

4. The analysis of the devices used in the monitoring of the state of the GD is carried out. The perspective direction of improvement of the complex for diagnostics of grounding «КД3-1У» is determined.

\section{REFERENCES}

1. Pravyla ulashtuvannja elektroustanovok [Electrical Installation Regulations]. Kharkiv, Fort Publ., 2017. 760 p. (Ukr).

2. Natsional'nyy standart Ukrayiny. SOU 31.2-2167768119:2009. Viprobuvannya ta kontrol' prystroyiv zazemlennya elektroustanovok. Tipova instruktsiya [National Standard of Ukraine SOU 31.2-21677681-19:2009. Test and control devices, electrical grounding. Standard instruction]. Kyiv, Minenergovugillya Ukrayiny Publ., 2010. 54 p. (Ukr).

3. Seljeseth H., Campling A., Feist K.H., Kuussaari M. Station Earthing. Safety and interference aspects. Electra, 1980, vol.71, pp. 47-69.

4. Boaventura W.C., Lopes I.J.S., Rocha P.S.A., Coutinho R.M., Castro F., Dart F.C. Testing and evaluating grounding systems of high voltage energized substations: alternative approaches. IEEE Transactions on Power Delivery, 1999, vol.14, no.3, pp. 923-927. doi: 10.1109/61.772335. 
5. Tabatabaei N.M., Mortezaeei S.R. Design of grounding systems in substations by ETAP intelligent software. International Journal on «Technical and Physical Problems of Engineering». 2010, iss.2, vol.2, no.1, pp. 45-49.

6. Kolechitsky Ye.S. Approximate estimates of the resistance of grounding devices. Vestnik MEI, 2006, no.4, pp. 56-62. (Rus).

7. IEEE Std 80-2000 Guide for Safety in AC Substation Grounding. New York, IEEE, 2000. 200 p. doi: 10.1109/ieeestd.2000.91902.

8. Link I.Yu., Koliushko D.G., Koliushko G.M. A mathematical model is not an equipotential ground grids substation placed in a double layer. Electronic modeling, 2003, vol.25, no.2, pp. 99-111. (Rus).

9. Koliushko D.G., Rudenko S.S. Determination the electrical potential of a created grounding device in a three-layer ground Technical Electrodynamics, 2018, no.4. pp. 19-24. (Rus). doi: 10.15407/techned2018.04.019.

10. IEEE Std 81-2012 Guide for Measuring Earth Resistivity, Ground Impedance, and Earth Surface Potentials of a Grounding System. New York, IEEE, 2012. 86 p. doi: 10.1109/ieeestd.2012.6392181.

11. Nizhevskyi I.V., Nizhevskyi V.I., Bondarenko V.E. The experimental validation of the grounding device resistance measurement method. Electrical engineering \& electromechanics, 2016, no.6, pp. 60-64 (Rus). doi: 10.20998/2074-272X.2016.6.10.

12. Tselebrovskiy Yu.V. The theory of measurement of resistance of earthing device. Proceedings of TUSUR, 2012, iss.1, part 1, pp. 196-198. (Rus).

13. Glebov O.Yu., Koliushko D.G., Link I.Yu. Determination of the touch voltage by the method of superposition of current components of a single-phase earth fault. Bulletin of NTU «KhPI», 2005, no.49, pp. 85-88. (Rus).

14. Salam M.A., Rahman Q.M., Ang S.P., Wen F. Soil resistivity and ground resistance for dry and wet soil. Journal of Modern Power Systems and Clean Energy, 2015, vol.5, no.2, pp. 290-297. doi: 10.1007/s40565-015-0153-8.

15. Fomenko O.V., Kostenko M.A., Novikova A.O. Influence of Communication Resistance on Damage of the Electronic Equipment in the Grounding Device. Global Nuclear Safety, 2014, no.3(12), pp. 44-48. (Rus).

16. Resursnye elementnye smetnye normy na puskonaladochnye raboty. Sbornik 1. Elektrotekhnicheskie ustroistva. DBN D.2.61-2000 [Resource elemental estimates for commissioning. Collection 1. Electrotechnical devices. DBN D.2.6-1-2000]. Kyiv, Derzhbudivnytstvo Ukrainy Publ., 2001. 49 p. (Rus).

17. Rudenko S.S. Requirements for devices for vertical electrical sounding of soil at diagnostics of grounding devices. Electrical engineering \& electromechanics, 2016, no.5, pp. 6873. (Rus). doi: 10.20998/2074-272X.2016.5.12.

Received 13.09.2018

D.G. Koliushko ${ }^{1}$, Candidate of Technical Science, Senior Research Associate,

S.S. Rudenko ${ }^{1}$, Candidate of Technical Science, Research Associate,

${ }^{1}$ National Technical University «Kharkiv Polytechnic Institute», 2, Kyrpychova Str., Kharkiv, 61002, Ukraine, e-mail: nio5_molniya@ukr.net

How to cite this article:

Koliushko D.G., Rudenko S.S. Analysis of methods for monitoring of existing energy objects grounding devices state at the present stage. Electrical engineering \& electromechanics, 2019, no.1, pp. 67-72. doi: 10.20998/2074272X.2019.1.11. 